\title{
Menakar Potensi Bank Syariah Di Indonesia Pada Masa Covid-19
}

\author{
1Erwin Saputra Siregar, ${ }^{2}$ Fitri Ana Siregar \\ 1UIN Sulthan Thaha Saifuddin Jambi, \\ 2Institut Agama Islam Negeri Padangsidimpuan \\ E-mail: ${ }^{1} \underline{\text { erwinsaputrasiregar@uinjambi.ac.id, }}{ }^{2}$ fitrianasiregar88@gmail.com
}

\begin{abstract}
Economic growth is an indicator used to see the success of development. Sharia economy is expected to be a solution.The purpose of research is to examine and explain the potential extent of Islamic banks in Indonesia.This research is library research, which is a series of activities relating to the methods of collecting library data, reading, taking notes and processing research materials. This study used a qualitative approach. The results of this study, the potential of existing Islamic banks can be optimized with third party funds and number of offices, which are variables that can increase the market share of Islamic banks in Indonesia. A simple and fast government policy to boost the market share of Islamic banks with the establishment of a Sharia BUMN Bank. The number of offices in the current era is not only physical, but must be supported by the latest information technology.
\end{abstract}

\section{Keywords: Potential, Islamic Bank, COVID-19}

\begin{abstract}
Abstrak
Pertumbuhan ekonomi merupakan indikator yang digunakan untuk melihat keberhasilan pembangunan. Ekonomi syariah yang diharapkan menjadi solusi dari lemahnya sistem ekonomi. Tujuan penelitian ini untuk menelaah dan memaparkan sejauh mana potensi bank syariah di Indonesia serta melihat peluang pembangunan ekonomi pada masa yang akan datang. Jenis penelitian ini adalah library research, yaitu serangkaian kegiatan yang berkenaan dengan metode pengumpulan data pustaka, membaca, dan mencatat serta mengolah bahan penelitian. Penelitian ini menggunakan pendekatan kualitatif. Hasil penelitian ini potensi bank syariah yang ada dapat dioptimalkan dengan dana pihak ketiga dan jumlah kantor yang merupakan variabel yang bisa menaikkan market share bank syariah di Indonesia. Kebijakan pemerintah yang sederhana dan cepat untuk mendongkrak market share bank syariah dengan berdirinya Bank BUMN Syariah. Jumlah kantor di era sekarang bukan hanya berbentuk fisik, tetapi harus didukung dengan teknologi informasi yang paling mutakhir. Jumlah kantor sangat bergantung pada aset yang dimiliki bank syariah,
\end{abstract}

\section{Kata Kunci: Potensi, Bank Syariah, COVID-19}

\section{Pendahuluan}

Pertumbuhan ekonomi merupakan indikator yang digunakan untuk melihat keberhasilan pembangunan. Sejalan dengan pendapat Ida, pertumbuhan ekonomi hingga kini masih digunakan sebagai indikator kemajuan perekonomian secara agregat. Pertumbuhan ekonomi menunjukkan peningkatan dalam produksi barang maupun jasa dalam suatu perekonomian, sehingga pertumbuhan ekonomi ini 
Erwin Saputra Siregar \& Fitri Ana Siregar

merupakan salah satu indikator penting di dalam melakukan suatu analisis pembangunan ekonomi(Nuraini, 2017).Indonesia sedang mengalami lemahnya sistem ekonomi disebabkan pandemiCOVID-19.Pertumbuhan ekonomi Indonesia pada tahun 2020 semula diperkirakan sebesar 5,3\%, namun angka ini terkoreksi sebagai dampak pandemi COVID-19, dan sebagian kalangan memprediksi pertumbuhan ekonomi di bawah 2\%(Hadiwardoyo, 2020).Badan Pusat Statistik merilis pertumbuhan ekonomi Indonesiapada periode Agustus 2020 menyebutkan bahwa pertumbuhan ekonomi Indonesia berada pada posisi minus 5,32\%. Salah satu penyebabnya karena pembatasan aktifitas yang diberlakukan oleh pemerintah. Pembatasan aktifitas akibat pandemi COVID-19 telah menimbulkan kerugian ekonomi secara nasional. Kerugian itu hanya akan tertutupi apabila krisis dapat diakhiri sebelum menimbulkan kebangkrutan usaha secara massal(Hadiwardoyo, 2020).

Indonesia yang merupakan salah satu negara berkembang senantiasa melakukan berbagai aktivitas ekonomi untuk mendukung keberlanjutan pembangunan nasional secara kontinu(Oktarina \& Asnaini, 2020). Salah satu unsur dalam pembangunan yang memiliki peran strategis adalah perbankan(Oktarina \& Asnaini, 2020). Kinerja ekonomi yang melemah ini berdampak pada kondisi perbankan di Indonesia saat ini. Sesuai fungsinya, perbankan seharusnya menjadi pembangkit ekonomi(Oktarina \& Asnaini, 2020). Perbankan menjadi lembaga intermediasi bagi masyarakat. Hal ini sejalan dengan pendapat Asnaini dan Aminah,perannya yang besar bagi pembangunan mendorong perbankan untuk senantiasa mendapatkan perhatian khusus dalam pengawasan agar pelaksanaan penghimpunan dan penyaluran dananya dapat tepat guna sesuai dengan tujuan dari pembangunan itu sendiri(Oktarina \& Asnaini, 2020).

Perbankan di Indonesia terdiri dari dua jenis, yaitu perbankan konvensional dan perbankan syariah. Industri perbankan dengan konsep syariah dan sistem bagi hasil yang dimiliki mampu membedakan dirinya dengan bank konvensional yang ada, dimana return yang dibagikan kepada pemilik dana (nasabah) lebih tinggi nilainya dari bunga yang ada pada bank konvensional(Andespa, 2017). Sebagaimana yang dikatakan Noor bahwa bank syariah adalah lembaga intermediasi dan penyedia jasa keuangan yang bekerjaberdasarkan etika Islam, seperti bebas bunga (riba), bebas dari praktik spekulatif (maysir), dan bebas dari hal yang meragukan (gharar)(Noor \& Sanrego, 2014).

Keberadaan perbankan syariah di Indonesia merupakan suatu perwujudan permintaan masyarakat yang membutuhkan suatu sistem perbankan alternatif yang 
menyediakan jasa perbankan atau keuangan yang sesuai dengan prinsip syariah. Hal ini disebabkan mayoritas penduduk Indonesia bergama Islam, berjumlah \pm 207 juta jiwa atau $87,2 \%$ dari total penduduk Indonesia(Indonesia.go.id, t.t.).Penduduk Indonesia berpandangan bahwa bunga bank itu bersifat haram. Hal ini sejalan dengan pendapat Ida bahwa bank syariah di Indonesia didirikan karena keinginan masyarakat terutama masyarakat yang beragama Islam yang berpandangan bunga merupakan hal yang haram, hal ini lebih diperkuat lagi dengan pendapat para ulama yang ada di Indonesia yang diwakili oleh Fatwa MUI Nomor 1 Tahun 2004 tentang bunga yang intinya mengharamkan bunga bank yang didalamnya terdapat unsur-unsur riba. Bagi masyarakat dimana seluruh aktivitasnya dijalankan berdasarkan etika dan prinsipprinsip Islam sehingga bebas dari unsur riba (bunga), bebas dari kegiatan spekulatif non-produktif seperti perjudian (maysir), bebas dari kegiatan yang meragukan (gharar),bebas dari perkara yang tidak sah (bathil), dan hanya membiayai usaha-usaha yang halal. (Nuraini, 2017) Sementara diolah dari data Statistik Perbankan Syariah Otoritas Jasa Keuangan (OJK), market share bank syariah per Juni 2020 hanya berkisar di angka 6,13\%(Stastistik Perbankan Syariah - September 2019, t.t.).

Memang market share yang dimaksud adalah pangsa pasar bank syariah terkait aset. Tetapi dengan aset penduduk Indonesia yang mayoritas Islam sebesar 87,2\% kenapa hanya dapat dikuasai bank syariah sebesar 6,13\%. Kemana potensi aset 81,07\% lagi, jawabannya belum bisa digaet oleh bank syariah. Sebagai informasi negara tetangga seperti Malaysia sudah menguasai pangsa pasar bank syariah di atas $25 \%$. Bonus demografi yang menjadi given dari Allah SWT terkadang tidak serta merta menjadi berkah buat Indonesia. Ekonomi syariah yang diharapkan menjadi jawaban dari lemahnya sistem ekonomi sebelum-sebelumya ternyata belum bisa berbuat banyak. Sampai saat inisistem ekonomi terdahulu masih merajai di Indonesia yaitusistemekonomikapitalisme(Hamid, 2014). Pengembangan bank syariah ke depan harus berdasarkan market driven dan tidak dapat hanya mendasarkan pada emosi keagamaan semata. Mengingat masalah umum yang dihadapi oleh masyarakat adalah masih rendahnya pemahaman terhadap bank syariah, maka proses mengedukasi masyarakat menjadi sangat penting(Mursadi \& Ratnawati, 2011).

Ditilik dari sejarahnya, saat ini bank syariah di Indonesia masih berusia 28 tahun ditandai dengan berdirinya Bank Muamalat Indonesia pada tanggal 1 November 1991. Dibanding dengan bank konvensional yang sudah lebih jauh melangkah, seperti BRI sudah berusia 124 tahun. Dilihat dari segi aset, Bank Syariah Mandiri merupakan bank syariah dengan aset terbesar yaitu 102,78 Triliun sementara BRI mempunyai aset sebesar 1.305,60 Trilun. Jarak yang begitu jauh ini memerlukan kebijakan khusus dari 


\section{Menakar Potensi Bank Syariah Di Indonesia \\ Pada Masa Covid-19}

Erwin Saputra Siregar \& Fitri Ana Siregar

pemerintah agar bank syariah dapat bergelora di Indonesia dengan potensi yang paling besar di dunia. Menurut Abu Ishaq al-Syayrazi, kebijakan pemerintah mempunyai peranan signifikan dalam mendorong pertumbuhan pembangunan ekonomi suatu negara. Pengambilan kebijakan selalu melibatkan pihak-pihak yan berkepentingan dalam rangka menegakkan keadilan bagi umat manusia. Tidak hanya dilihat dari prosesnya tetapi juga kontribusinya kepada masyarakat luas. Kebijakan yang zalim akan membawa kemudharatan. Kebijakan seperti ini mesti ditinjau kembali akan tetapi wajib dibatalkan(Zawawi, 1999).

Tujuan penulisan ini yaitu untuk menelaah dan memaparkan sejauh mana potensi bank syariah di Indonesia serta melihat peluang positif atau negatifnya terhadap pembagunan ekonomi kedepannya.

\section{Tinjauan TEORITIK}

Perbankan merupakan sebuah lembaga yang memiliki peran strategis dalam pembagunan. Hal ini sejalan dengan pernyataan Oktarina bahwa salah satu unsur dalam pembangunan yang memiliki peran strategis adalah perbankan (Oktarina\&Asnaini, 2020). Lebih lanjut, Andrew mengatakan peranan bank di Indonesia adalah sangat penting, khususnya dalam pembangunan ekonomi, dimana bank berfungsi sebagai lembaga intermediasi antara pihak penyimpan dana sebagai pihak yang surplus dana dengan pihak yang membutuhkan dana sebagai pihak yang minus(Utama, 2018). Sebagaimana diamanatkan oleh Pancasila dan Undang-Undang Dasar Negara Republik Indonesia Tahun 1945, tujuan pembangunan nasional adalah terciptanya masyarakat adil dan makmur berdasarkan demokrasi ekonomi dengan mengembangkan sistem ekonomi yang berkeadilan(Utama, 2018).

Bank Syariah merupakan salah satu produk perbankan yang berlandaskan sistem perekonomian Islam, Sistem Ekonomi Islam atau syariah sekarang ini sedang banyak diperbincangkan di Indonesia(Marimin\&Romdhoni, 2015). Bank syariah merupakan lembaga keuangan yang berfungsi memperlancar mekanisme ekonomi disektor rill melalui aktivitas kegiatan usaha (investasi, jual beli, atau lainnya) berdasarkan prinsip Syariah(Oktarina\&Asnaini, 2020). Rivai mengatakan, Bank syariah merupakan lembaga intermediasi dan penyedia jasa keuangan yang bekerja berdasarkan etika dan sistem nilai Islam, khususnya yang bebas dari bunga (riba), bebas dari kegiatan spekulatif yang non produktif seperti perjudian (maysir), bebas dari hal-hal yang tidak jelas dan meragukan (gharar), berprinsip keadilan, dan hanya membiayai kegiatan usaha yang halal. Bank syariah sering dipersamakan dengan bank 
tanpa bunga. Bank tanpa bunga merupakan konsep yang lebih sempit dari bank syariah, ketika sejumlah instrument atau operasinya bebas dari bunga. Bank syariah, selain menghindari bunga, juga secara aktif turut berpartisipasi dalam mencapai sasaran dan tujuan dari ekonomi Islam yang berorientasi pada kesejahteraan social(Veithzal, 2007).

Undang-Undang Nomor 10 Tahun 1998 Pasal 1 Ayat 13 tentang perbankan menyatakan apa yang dimaksud dengan prinsip syariah yakni: "Prinsip syariah adalah aturan perjanjian berdasarkan hokum islam antara bank dan pihak lain untuk penyimpanan dana dan atau pembiayaan kegiatan usaha,atau kegiatan lainnya yang dinyatakan sesuai dengan syariah, antara lain pembiayaan berdasarkan prinsip bagi hasil (mudharabah), pembiayaan berdasarkan penyertaan modal (musyarakah), prinsip jual beli barang dengan memperoleh keuntungan (mudharabah), atau pembiayaan barang modal berdasarkan prinsip sewa murni tanpa pilihan (ijarah). Atau dengan adanya pemindahan kepemilikan atas barang yang disewa dari pihak bank oleh pihak lain (ijarah waiqtina)".

Bank Syariah memiliki misi dan metodologi yang ekslusif, misi yang bukan sekedar ada pada jumlah nominal investasi tapi juga mencakup pada jenis, objek dan tujuannya itu sendiri. Adapun metodologinya adalah kerangka syariat dan kaidahkaidahnya yang bersumber dari etika dan nilai-nilai syariat Islam yang universal. Berdasarkan hal tersebut, Bank syariah berfungsi sebagai sarana untuk mengumpulkan tabungan masyarakat dan mengembangkannya. Intinya bahwa Bank syariah adalah lembaga yang berfungsi untuk menginvestasikan dana masyarakat sesuai dengan anjuran Islam dengan efektif, produktif dan untuk kepentingan umat Islam. Tujuan utama dari Bank Syariah, yaitu menyatukan umat Islam, mengembalikan kekuatan, peran, dan kedudukan Islam di muka bumi ini bisa tercapai.(Marimin\&Romdhoni, 2015) Bank syariah merupakan bank yang memiliki segmen pasar tersendiri yakni pasar religiusitas yang tinggi(Sidharta, 2018). Untuk itu, bank syariah dapat memanfaatkan emotional brand image. Emotional brand image merupakan cara bagi perusahaan untuk dapat menggunakan komunikasi pemasaran yang mencoba untuk mendengarkan keinginan, aspirasi dan kebutuhan dari para calon konsumen(Thompson dkk., 2006). Kelebihan Bank Syariah terutama pada kuatnya ikatan emosional keagamaan antara pemegang saham, pengelola bank, dan nasabahnya. Dari ikatan emosional inilah dapat dikembangkan kebersamaan dalam menghadapi risiko usaha dan membagi keuntungan secara jujur dan adil(Antonio, 2008). 


\section{Menakar Potensi Bank Syariah Di Indonesia \\ Pada Masa Covid-19}

Erwin Saputra Siregar \& Fitri Ana Siregar

Berdasarkan hasil dari pengolahan data primer melalui SPSS dengan uji hipotesis, maka ditemukan output bahwa keberadaan PT. Bank Aceh Syariah di Aceh memberikan pengaruh positif bagi kesejahteraan masyarakat. Dengan kata lain, sebagian besar warga Aceh berpendapat bahwa pengaruh dari adanya BPD Aceh telah membantu taraf kesejahteraan perekonomian mereka. Namun demikian, hal yang perlu diperhatikan di hasil data ini ialah $64 \%$ dari koresponden mengambil pembiayaan murabahah. Nilai tersebut merupakan nilai terbesar dari hasil penelitian ini untuk akad kerjasama yang dilakukan oleh koresponden. Nilai ini berbanding terbalik dengan akad lainnya yaitu akad mudharabah yang dilakukanhanya 3\%, 2\% persen untuk akad musyarakah, akad qardul hasan 4\% dan $1 \%$ untuk ijarah. Padahal menurut hasil dari pertanyaan yang diajukan oleh peneliti kepada koresponden tentang keinginan mereka untuk mengambil pembiayaan mudharabahah, 64\% dari koresponden menjawab setuju dan sangat setuju. Begitu juga dengan akad qardulhasan dengan jawaban setuju dan sangat setuju untuk melakukan akad tersebut di Bank Aceh Syariah sebanyak 73\%.

Merujuk kepada hasil wawancara dengan pegawai bidang pembiayaan Bank Aceh Syariah, menyebutkan bahwa tidak adanya pembiyaan mudharabah dan hanya sedikit nasabah yang memperoleh pembiayaan qardulhasan (Wawancara dengan Zulkhairi, Khairunnisa, Ahmad Firman (Staff PT. BAS): 11 Juni, 15 Oktober, 10 November 2019). Padahal qardulhasan merupakan pembiayaan yang sangat berpengaruh untuk mengurangi angka kemiskinan(Widiyantodkk., 2011). Namun pembiayaan qardhulhasan belum mendapat perhatian yang serius dari perbankan syariah sebagai perwujudan fungsi sosial perbankan syariah. Begitu juga dengan mudharabah yang sangat membantu masyarakat yang membutuhkan modal untuk usahanya. Sebagaimana menurut Junaidi, dkk menyatakan bahwa produk perbankan syariah lebih berorientasi pada program yang mengandung nilai laba (Junaidi et al, 2017: 421-431).

Dalam hal ini, meskipun murabahah telah menjadi pilihan masyarakat sebagai tolak ukur kesejahteraan mereka dari hasil kuisioner yang diperoleh, tetapi murabahah lebih difokuskan kepada praktek jual beli dan bahkan dalam dunia perbankan sendiri akad ini secara jelas dinamai dengan akad jual beli Murabahah seperti yang diterapkan di Bank Muamalah Kendari (A. Baktiar, et.al, 2017: 13-27). Sehingga dapat disimpulkan bahwa nasabah secara tidak langsung membeli barang dari bank, bukan memperoleh modal untuk usaha mereka. Idealnya, cara untuk mengentaskan kemiskinan ialah dengan peningkatan tingkat pendapatan dengan program-program 
yang berpihak pada kaum miskin, mencapai distribusi pendapatan yang adil dan memberikan peluang yang sama bagi semua segmen social. Maka jelaslah di sini bahwa program-program yang dapat membantu pertumbuhan ekonomi rakyat menengah kebawah ialah dengan penyaluran modal melalui mudharabah dan qardulhasan.

\section{Metode Penelitian}

Jenis penelitian ini adalah library research, yaitu serangkaian kegiatan yang berkenaan dengan metode pengumpulan data pustaka, membaca dan mencatat serta mengolah bahan penelitian (Zed, 2004, hlm. 3). Penelitian ini menggunakan pendekatan kualitatif, karena sifat penelitiannya adalah deskriptif yang menjelaskan data-data yang diperoleh apa adanya secara sistematis. Penelitian ini juga dilakukan penyelidikan secara mendalam mengenai subjek tertentu agar memberikan gambaran yang lengkap mengenai subjek tersebut. Dalam penelitian ini, data yang digunakan adalah data sekunder yaitu data diperoleh dari literatur-literatur kepustakaan seperti data dari website diktis dan buku-buku terkait perbankan syariah. Adapun teknik pengumpulan data yang pada penelitian ini menggunakan library research yaitu pengumpulan data yang berasal dari data pustaka. Data yang diperoleh kemudian dilakukan analisis data dengan teknik analisis deskriptif. Dalam penelitian ini, penulisakan membaca dan menelaah berbagai sumber yang berkaitan dengan topik untuk kemudian dilakukan analisis dan menarik kesimpulan yang akan dituangkan secara tertulis.

\section{Hasil Dan Pembahasan}

Suatu fenomena yang menarik, Bank Muamalat Indonesia merupakan bank syariah pertama di Indonesia beridiri tahun 1991, sementara Bank Syariah Mandiri merupakan bank syariah terbesar di Indonesia berdiri tahun 1999. Normalnya Bank Muamalat Indonesia menjadi bank syariah terbesar karena lebih lama berkiprah. Menjadi dilema mungkin ketika kebijakan pemerintah menimbulkan hasil yang berbeda dari kedua bank syariah terbesar di Indonesia itu. Artinya pemerintah seharusnya melalui KNKS bisa mendongkrak bank syariah secara menyeluruh. Salah satu wacana lawas tahun 2015 yang sampai sekarang belum terealisasi adalah pendirian Bank BUMN Syariah dengan memerger Bank Syariah Mandiri, BRI Syariah, BNI Syariah, dan mengakuisisi BTN Syariah(Kajian Kebijakan Pemerintah | Penguatan Perbankan Syariah: Merger AtauKonsolidasi, t.t.). Wacana ini sebenarnya bisa jadi oase untuk perkembangan bank syariah di Indonesia. Dengan adanya Bank 


\section{Menakar Potensi Bank Syariah Di Indonesia \\ Pada Masa Covid-19}

Erwin Saputra Siregar \& Fitri Ana Siregar

BUMN Syariah, berbagai kebijakan pemerintah dalam rangka memompa market share bank syariah lebih mudah terealisasi.

Dana Pihak Ketiga dan Jumlah Kantor merupakan variabel yang bisa menaikkan market share bank syariah di Indonesia(Siregar, 2019, hlm. 46-48). Berikut ulasan akan dijelaskan penulis satu per satu. Pertama, dana pihak ketiga pada dasarnya tergantung dengan pemahaman masyarakat tentang bank syariah. Hal ini sejalan dengan yang ditemukan pada studi yang lain bahwa secara umum faktor pengetahuan dan akses berpengaruh positif terhadap preferensi masyarakat dalam memilih serta menabung di perbankan Syariah di DKI Jakarta, sebaliknya fasilitas dan profesionalitas berpengaruh negatif(Noor \&Sanrego, 2014). Masyarakat di Indonesia umumnya menganggap "bank syariah sama saja dengan bank konvensional". Masyarakat lebih cenderung melihat yang mana yang lebih murah dan yang mana yang lebih untung.

Padahal Majelis Ulama Indonesia (MUI) melalui Dewan Syariah Nasional telah mengeluarkan fatwa sebanyak 125 kali untuk mengatur kesyariahan dari bank syariah atau lembaga keuangan syariah. Fakta ini membuat bank syariah banyak berharap kepada akademisi, ustadz, dan mahasiswa yang mendalami bank syariah agar bisa memberikan pemahaman kepada masyarakat. Hal ini merupakan sesuatu yang bisa dikerjakan tetapi sangat rumit. Fakta lain, beberapa ustadz yang memberikan pencerahan kepada masyarakat berbeda pendapat juga tentang bank syariah ini. Ada beberapa ustadz mengatakan bank syariah sudah sesuai dengan syariah Islam, ada beberapa ustadz yang mengatakan bank syariah belum sesuai dengan syariah Islam. Hal ini juga yang membuat masyarakat bingung dan pada akhirnya memilih untuk tidak memilih menggunakan bank syariah dan market share bank syariah stagnan.

Kebijakan pemerintah yang sederhana dan cepat untuk mendongkrak market share bank syariah di Indonesia. Dengan berdirinya Bank BUMN Syariah, pemerintah bisa mengeluarkan kebijakan, khusus Pegawai Negeri Sipil di seluruh Indonesia yang beragama Islam wajib menerima gaji di Bank BUMN Syariah. Menurut data dari Badan Kepegawaian Negara (BKN) jumlah Pegawai Negeri Sipil di Indonesia adalah 4,3 juta, sedangkan Pegawai Negeri Sipil yang beragama Islam berjumlah 3,5 juta. Jika diasumsikan rata-rata gaji Pegawai Negeri Sipil yang beragama Islam sebesar 5 juta per bulan maka bank syariah akan mendapatkan suntikan dana di awal bulan sebesar 17,5 Triliun. Jumlah yang sangat fantastis dan sangat signifikan untuk mendongkrak market share bank syariah. Jika diasumsikan setiap Pegawai Negeri Sipill tersebut menarik gajinya dari bank syariah sebesar 80\% maka bank syariah mendapatkan dana 
yang mengendap sebesar 3,5 Triliun per bulan. Bank syariah akan semakin cepat melesat, terkait pemahaman masyarakat tentang bank syariah Pegawai Negeri Sipil Muslim yang berjumlah 3,5 juta orang akan berpengaruh baik karena minimal mereka bertransaksi satu kali dalam sebulan. Implikasinya masyarakat yang dekat dengan mereka juga pada akhirnya akan paham dengan bank syariah dan diharapkan menjadi nasabah bank syariah juga. Selain Pegawai Negeri Sipili masih banyak potensi yang bisa difokuskan oleh bank syariah, seperti komunitas hijrah yang marak sekarang dan komunitas-komunitas muslim lainnya.

Kedua, jumlah kantor di era sekarang bukan hanya berbentuk fisik, tetapi harus didukung dengan teknologi informasi yang mutakhir. Jumlah kantor sangat bergantung pada aset yang dimiliki bank syariah, semakin besar aset maka kemungkinan jumlah kantor akan semakin banyak. Selain itu, dana pihak ketiga juga menjadi komponen utama dari jumlah kantor. Dengan peningkatan dana pihak ketiga akan meningkatkan jumlah nasabah, nasabah memerlukan kehadiran kantor dalam bentuk fisik maupun teknologi. Pengaruhnya lagi ketika jumlah kantor meningkat secara jumlah fisik dan teknologi, akan menjadi sosialisasi otomatis untuk masyarakat. Apalagi masyarakat yang sama sekali belum mengenal bank syariah, belum pernah melihat kantor bank syariah, apalagi melihat fitur teknologi bank syariah. Secara teknologi masyarakat juga sudah lebih melek sehingga peningkatan teknologi bank syariah bisa menjadi senjata utama untuk merekrut nasabah-nasabah baru. Kualitas layanan menjadi salah satu faktor yang menentukan bagi masyarakah untuk menjadi nasabah bank syariah. Sehingga, kantor dan jaringan ATM merupakan salah satu faktor kunci bagi bank syariah untuk mendapatkan nasabah-nasabah baru. (Sidharta, 2018) Sebagian besar konsumen sangat setuju apabila bank syariah membuka cabang di seluruh Indonesia, banyak konsumen yang akan menggunakan jasa bank tersebut. Apabila ada suatu kasus, bank syariah memberitahukan bahwa investasi dan tabungan tidak menghasilkan laba dalam beberapa tahun, yang dilakukan sebagian besar nasabah adalah tetap menabung di tempat yang sama atau bank syariah yang lain, karena menabung di bank yang bukan syariah sangat bertentangan dengan prinsip islam(Adawiyah, 2015).

Sosialisasi telah dilakukan untuk melihat pemahaman masyarakat tentang perbankan syariah di satu rukun tetangga. Dari \pm 100 orang yang telah dikunjungi, tidak sampai 10\% yang sudah paham tentang perbankan syariah. Masyarakat yang dikunjungi seluruhnya beragama Islam. Masyarakat lebih mengenal bank-bank konvensional tanpa peduli itu sesuai dengan syariah Islam atau tidak. Temuan lain yang didapatkan bahwa penyebab berpengaruh negatifnya fasilitas dan profesionalitas 


\section{Menakar Potensi Bank Syariah Di Indonesia \\ Pada Masa Covid-19}

Erwin Saputra Siregar \& Fitri Ana Siregar

dilandasi dengan minimnya pengetahuan masyarakat pesantren terhadap bank syariah, hal ini dibuktikan dengan minimnya responden yang menjadi nasabah bank syariah. Pengetahuan masyarakat pesantren terhadap bank khususnya bank syariah sangat minim, hal ini dibuktikan dengan banyaknya responden yang menyatakan belum mengetahui akan bank syariah dan belum menjadi nasabah bank Syariah(Noor \&Sanrego, 2014).

Masyarakat hanya berpikir sederhana, yaitu yang terpenting uang tersimpan dengan aman dan mudah untuk mengambilnya. Satu sisi lagi, bank konvensional lebih dekat dengan masyarakat terkait bantuan modal untuk usaha-usaha mikro. Masyarakat butuh modal, dengan cepat bank konvensional hadir dengan harga yang murah. Sementara bank syariah masih timbul tenggelam di tengah-tengah masyarakat. Banyak juga masyarakat yang bersikeras dengan pandangannya bahwa bahwa bank syariah hanya ganti baju, semua bank yang ada di Indonesia sama saja. Bahkan ada sebagian masyarakat yang sudah mengerti tentang bank syariah tapi enggan untuk move on ke bank syariah, terkadang mencari kesalahan bank syariah dan dijadikan alasan keengganannya untuk pindah.

Jadi, dengan potensi bank syariah yang sangat besar di Indonesia bahkan terbesar di dunia harusnya pemerintah mempersiapkan strategi dan kebijakan khusus. Gambaran sederhana yang penulis paparkan mungkin masih ada celah kelemahan, tetapi hal sesederhana itu sebenarnya sangat signifikan untuk perkembangan bank syariah. Perlahan tapi pasti dengan kenaikan aset bank syariah setiap bulannya dari dana mengendap Pegawai Negeri Sipil yang beragama Islam, bank syariah bisa melakukan ekspansi bisnis. Bank Syariah pada dasarnya memiliki potensi dan peluang yang luar biasa besar. Pertumbuhan dari segi aset pun sudah membuktikan bahwa Bank Syariah merupakan model bank yang sangat ideal untuk mendorong kemajuan perekonomian Negara(Marimin\&Romdhoni, 2015).Jika sebelumnya bank syariah tidak bisa membiayai proyek-proyek besar karena kekurangan aset maka dengan peningkatan itu bank syariah bisa bersaing dengan bank konvensional. Jika sebelumnya bank syariah mahal di benak masyarakat, maka dengan peningkatan aset tersebut bank syariah bisa memberikan harga yang lebih bersaing dengan bank konvensional. Bank syariah seperti kurcaci yang dibiarkan tumbuh kembang menghadapi monster (bank konvensional) di Indonesia, sangat tidak memungkinkan. Selain dari segi kesyariahan, dukungan kebijakan pemerintah, dukungan dari para akademisi, ustadz, dan mahasiswa, bank syariah secara mandiri juga harus lebih kreatif dan inovatif dalam memasarkan produk-produknya. Bisa memberikan penjelasan yang 
nyata bahwa bank syariah memiliki keunggulan-keunggulan. Bank syariah juga harus membenahi stigma-stigma yang menyatakan bank syariah tidak sesuai syariah, dengan lebih meningkatkan kemampuan mengenai bank syariah kepada para pegawai dan akhirnya bisa menelurkan produk yang benar-benar sesuai syariah dan nyaman di hati masyarakat.

\section{Kesimpulan}

Pertumbuhan ekonomi merupakan indikator yang digunakan untuk melihat keberhasilan pembangunan. Perbankan merupakan sebuah lembaga yang memiliki peran strategis dalam pembagunan. Bank Syariah memilikimisi danmetodologi yang ekslusif, misi yang bukan sekedar ada pada jumlah nominal investasitapi juga mencakup pada jenis, objek dan tujuannya itu sendiri. Potensi bank syariah yang ada dapat dioptimalkan dengan Dana Pihak Ketiga dan Jumlah Kantor yang merupakan variabel yang bisa menaikkan market share bank syariah di Indonesia. Kebijakan pemerintah yang sederhana dan cepat untuk mendongkrak market share bank syariah dengan berdirinya Bank BUMN Syariah. Jumlah kantor di era sekarang bukan hanya berbentuk fisik, tetapi harus didukung dengan teknologi informasi yang mutakhir. Jumlah kantor sangat bergantung pada aset yang dimiliki bank syariah, semakin besar aset maka kemungkinan jumlah kantor akan semakin banyak. Ekonomi syariah yang diharapkan menjadi jawaban dari lemahnya sistem ekonomi.

\section{Daftar Pustaka}

Adawiyah, W. R. (2015). Pertimbangan, pengetahuan, dan sikapkonsumenindividuterhadap bank syariah. JurnalEkonomi Pembangunan: Kajian MasalahEkonomi dan Pembangunan, 11(2), 191-201.

Andespa, R. (2017). PengaruhBudaya dan KeluargaTerhadapMinatMenabungNasabah di Bank Syariah. Maqdis: Jurnal Kajian Ekonomi Islam, 2(1), 35-49.

Antonio, M. S. (2008). Bank Syariah: Analisis Kesehatan, Peluang, Kelemahan dan Ancaman. Ekononesia.

Hadiwardoyo, W. (2020). KerugianEkonomi Nasional AkibatPandemi Covid-19. BASKARA: Journal of Business \& Entrepreneurship, 2(2), 83-92.

Hamid, E. S. (2014). Perekonomian Indonesia.

Indonesia.go.id, R. (t.t.). Agama. Indonesia.Go.Id. Diambil 20 Desember 2019, dari https://indonesia.go.id/profil/agama

Kajian KebijakanPemerintah | PenguatanPerbankan Syariah: Merger AtauKonsolidasi. (t.t.). Diambil 20 Desember 2019, dari https://fiskal.kemenkeu.go.id/dw-kontenview.asp?id=20151230163122487266209 


\section{Menakar Potensi Bank Syariah Di Indonesia \\ Pada Masa Covid-19}

Erwin Saputra Siregar \& Fitri Ana Siregar

Marimin, A., \&Romdhoni, A. H. (2015). Perkembangan Bank Syariah Di Indonesia. JurnalIlmiahEkonomi Islam, 1(02).

Mursadi, M. C., \&Ratnawati, A. (2011). Potensi dan StrategiPengembangan Bank Syari ah di Indonesia: Kajian ProdukSyari ah dariSegiFiqih $\mathrm{Mu}$ amalat. Jurnal Hukum Islam IAIN Pekalongan, 9(2), 37022.

Noor, F., \&Sanrego, Y. D. (2014). Preferensi Masyarakat PesantrenTerhadap Bank Syariah (StudiKasus DKI Jakarta). Tazkia Islamic Finance and Business Review, 6(1).

Nuraini, I. (2017). Kualitaspertumbuhanekonomidaerahkabupaten/kota di jawatimur. JurnalEkonomi Pembangunan, 15.

Oktarina, A., \&Asnaini, A. (2020). PotensiKontribusiInstitusi Pendidikan Islam TerhadapPerkembangan Bank Syari'ah di Indonesia. Al-Intaj: JurnalEkonomi dan Perbankan Syariah, 6(1), 51-58.

Sidharta, R. B. F. I. (2018). Optimalisasi Peran Perbankan Syariah DalamMendukungWisata Halal. JurnalDistribusi, 5(2), 1-14.

Siregar, E. S. (2019). AnalisisPengaruhFaktor Internal dan EksternalPerbankan Syariah terhadap Market Share AsetPerbankan Syariah di Indonesia. Zhafir| Journal of Islamic Economics, Finance, and Banking, 1(1), 39-50.

StastistikPerbankan Syariah-September 2019. (t.t.). Diambil 8 Desember 2020, dari https://www.ojk.go.id/id/kanal/syariah/data-dan-statistik/statistikperbankan-syariah/Pages/Stastistik-Perbankan-Syariah---September2019.aspx

Thompson, C. J., Rindfleisch, A., \&Arsel, Z. (2006). Emotional branding and the strategic value of the doppelgänger brand image. Journal of marketing, 7O(1), $50-64$.

Utama, A. S. (2018). IndependensiPengawasanTerhadap Bank Badan Usaha Milik Negara (BUMN) DalamSistem Hukum Nasional Di Indonesia. Soumatera Law Review, 1(1), 1-21.

Veithzal, R. (2007). Bank and Financial Institute Management. Jakarta: PT. Raja GrafindoPersada.

Widiyanto, W., Mutamimah, S., \&Hendar, H. (2011). Effectiveness of Qard Al-Hasan Financing as A Poverty Alleviation Model. Economic Journal of Emerging Markets, 3(1), 27-42. https://doi.org/10.20885/ejem.v3i1.2318

Zawawi, A. (1999). Penjelasan al-Qur'an tentangkrisissosial, ekonomi, dan politik. GemaInsani.

Zed, M. (2004). MetodePenelitianKepustakaan. Yayasan Obor Indonesia. 